\title{
Analysis of epigenetic modifications of chromatin at specific gene loci by native chromatin immunoprecipitation (N-ChIP) of nucleosomes isolated using hydroxyapatite chromatography.
}

\author{
Marjorie Brand ${ }^{1,2}$, Shravanti Rampalli', Chandra-Prakash Chaturvedi', and F. \\ Jeffrey Dilworth ${ }^{1,2}$
}

${ }^{1}$ Sprott Center for Stem Cell Research, Ottawa Health Research Institute, 501 Smyth Rd, Mailbox 511, Ottawa, ON, Canada, K1H 8L6; ' 2 Department of Cellular and Molecular Medicine, University of Ottawa, ON, Canada, K1H $8 \mathrm{~L} 6$.

Corresponding Authors: jdilworth@ohri.ca (F.J.D.), mbrand@ohri.ca (M.B.)

Phone (613) 737-8899 x 70339

Fax (613) 739-6294

\section{Category:}

Functional Analysis; Cell and Tissue Culture; Gene Expression

\section{Keywords:}

Native ChIP, Histone Modification, Chromatin, Gene Expression, Micrococcal Nuclease, Nucleosomes, Hydroxyapatite purification

\section{Abstract:}

Chromatin immunoprecipitation (ChIP) is routinely used to examine epigenetic modification of histones at specific genomic locations. However, covalent modifications of histone tails can serve as docking sites for chromatin regulatory factors. As such, association of these regulatory factors with chromatin could cause steric hindrance for antibody recognition, resulting in an underestimation of the relative enrichment of a given histone modification at specific loci. To overcome this problem, we have developed a native ChIP protocol to study covalent modification of histones that takes advantage of hydroxyapatite (HAP) 
chromatography to wash away chromatin-associated proteins prior to the immunoprecipitation of nucleosomes. This fast and simple procedure consists of 5 steps: nuclei isolation from cultured cells; fragmentation of chromatin using MNase; purification of nucleosomes using HAP; immunoprecipitation of modified nucleosomes; and qPCR analysis of DNA associated with modified histones. Nucleosomes prepared in this manner are free of contaminating proteins, and permit an accurate evaluation of relative abundance of different covalent histone modifications at specific genomic loci. Completion of this protocol requires approximately 1.5 days.

\section{Introduction:}

Epigenetic modification of chromatin plays an important role in establishing the many different cell types that share the same genome within an organism. To understand the role of epigenetics in regulating different cellular processes, chromatin immunoprecipitation (ChIP) is used extensively to evaluate the presence of different chromatin modifications at specific genomic locations. Chromatin states that are currently evaluated by ChIP include both posttranslational modifications of histones ${ }^{1-3}$, and methylation of $\mathrm{DNA}^{4}$. Conditions vary slightly amongst the many ChIP protocols currently in use, but these methods can be classified into one of two groups: 1) those which use chromatin isolated under native cellular conditions - Native ChIP $(\mathrm{N}-\mathrm{ChIP})^{1,2,5}$; or 2) those which use chromatin isolated from cells where proteins and DNA have been 
covalently bound to each other - Cross-linked ChIP (X-ChIP) $)^{6,7}$. The advantages of N-ChIP over X-ChIP have been described ${ }^{2}$, and include predictability of antibody specificity; efficiency of precipitation; and ability to analyze DNA without PCR amplification. The main disadvantage of NChIP is that it is mostly limited to studying histone modifications since proteins must be tightly associated with chromatin to be co-precipitated (unpublished observation). Thus, in most cases, it can be viewed that N-ChIP is the technique of choice to study post-translational modifications of histones or DNA, while X-ChIP is the method of choice for studying chromatin associated factors (i.e. transcriptional activators/repressor; cofactors; DNA repair factors). This being said, it has been shown over the last few years that many covalently modified histone tails can act as docking sites for chromatin regulatory factors ${ }^{8-10}$ - part of the histone $\operatorname{code}^{11}$. In this code, different covalent histone modifications are recognized, and become stably associated to regulatory factors via specific interaction domains ${ }^{12}$. An example of such an interaction is the recruitment of TFIID to specific promoters through the interaction of TAF3 (via its PHD domain) with $\mathrm{H} 3 \mathrm{~K} 4 \mathrm{me} 3^{13}$. As such, there is potential for these chromatin regulatory factors to cause steric hindrance for antihistone antibodies, resulting in an underestimation of a particular modification's relative enrichment at a genomic location of interest. To overcome this problem, we have developed a modified N-ChIP protocol (HAP-ChIP) that removes cofactors that might cause steric hindrance prior to immunoprecipitation (see Figure 1). 
Standard N-ChIP protocols are performed on non-purified nucleosomes extracted from nuclei ${ }^{1,5}$. Here, we have established an improved NChIP procedure that takes advantage of the high-affinity interaction between DNA and hydroxyapatite $(\mathrm{HAP})^{14}$ to obtain nucleosomes that are free of contaminating cofactors. Washes of $600 \mathrm{mM} \mathrm{NaCl}$ are commonly used to remove proteins (including histone $\mathrm{H} 1$ ) from chromatin in the preparation of purified histones by HAP chromatography ${ }^{15}$. In that technique, purified histone octamers are eluted from DNA using $2 \mathrm{M} \mathrm{NaCl}$. In contrast, our protocol elutes nucleosomes by increasing the phosphate concentration in the buffer to $500 \mathrm{mM} \mathrm{NaPO}_{4}$ at $\mathrm{pH} 7.2$ in the presence of low $\mathrm{NaCl}$ concentrations. This procedure preserves the interaction of DNA with the core histones, resulting in a concentrated population of pure nucleosomes that can be diluted for immediate use in immunoprecipitation. This procedure requires significantly less time than those which isolate chromatin over a sucrose gradient ${ }^{2}$, and has been optimized for analysis of genomic loci using qPCR. Indeed, the nucleosomal arrays obtained from this procedure, ranging from 1 to 3 nucleosomes, provides a genomic resolution for histone modifications of approximately $500 \mathrm{bp}$. This is ideal for qPCR analysis of genomic loci where the positioning of the nucleosomes has not yet been characterized. Since the standard size of amplicons for qPCR range from 80-200 bp, the use of shorter nucleosomal arrays (ie. mononucleosomes) greatly decreases the probability that a given primer/probe sets will lie within the same mononucleosome. A second important advantage of our protocol is that 
nuclei are lyzed using high concentrations of $\mathrm{NaCl}$ immediately following fragmentation by micrococcal nuclease, thereby resulting in an even representation of the different types of chromatin (euchromatin vs heterochromatin) in our preparation (see Figure 2). This is in contrast to the passive diffusion of fragmented chromatin from the nucleus that is used in other $\mathrm{N}$-ChIP protocols and could potentially result in the overrepresentation of regions of chromatin that are transcriptionally active. Our improved protocol was successfully used to examine the relative enrichment of trimethylation at lysine 4 of histone $\mathrm{H} 3$ (H3K4me3) within the 5' end of genes activated during myogenesis in $\mathrm{C} 2 \mathrm{C} 12$ cells $^{16}$. In these studies, we demonstrated that $\mathrm{H} 3 \mathrm{~K} 4 \mathrm{me} 3$ was greatly enriched at muscle specific genes at a time point coinciding with their expression. Furthermore, we demonstrated that Ash2L-containing histone methyltransferase complexes were responsible for establishing this epigenetic mark, and that this complex was targeted to specific promoters by a p38-dependent phosphorylation of Mef2d ${ }^{16}$.

The protocol described below has been optimized for qPCR analysis of genomic loci, but could easily be adapted to the recently described methods of ChIP-microarrays ${ }^{17,18}$, or ChIP-sequencing ${ }^{19}$. However, to maximize the potential of these powerful techniques, the user should modify conditions to increase the resolution of the ChIP by isolating mononucleosomes prior to immunoprecipitation. This could be accomplished by applying the nucleosomes eluted from the HAP column to a sucrose gradient prior to immunoprecipitation 
as described in the N-ChIP protocol developped by O'Neill and Turner². Similarly, HAP-ChIP can be adapted to the recently described carrier ChIP (CChIP) protocol which permits ChIP on as few as 100 mammalian cells ${ }^{3}$. While we have not yet tested the protocol on as few as 100 cells, we have successfully used it to examine the methylation status of several muscle specific genes in as few as 50,000 primary mouse myoblasts (data not shown). Under these conditions, we observe enrichment of various histone modification at levels equal to or greater than those observed in conditions where we start with $10^{7} \mathrm{C} 2 \mathrm{C} 12$ cells (data not shown). Finally, we believe that our ChIP protocol could be easily adapted to immunoprecipitation of methylated DNA (MeDIP) ${ }^{4}$.

\section{Experimental design}

In the protocol below, we describe conditions for analyzing epigenetic modifications of histones at specific genomic loci. This approach is outlined schematically in Figure 1. Description of this procedure has been divided into five steps that take about 1.5 days to complete. These steps include: 1) isolation of nuclei $(2 \mathrm{~h})$; 2) fractionation of chromatin using MNase $(0.25 \mathrm{~h})$; 3) purification of nucleosomes using hydroxyapatite $(0.5 \mathrm{~h}) ; 4)$ immunoprecipitation of nucleosomes $(20 \mathrm{~h})$; and 5) real-time PCR analysis of DNA associated with modified histones $(3 \mathrm{~h})$. This is a very simple protocol to implement, but there are several variables to consider before starting:

\section{Controls}


a) Amount of chromatin input into the ChIP.

When comparing two biological samples for epigenetic modifications, you should begin with similar amounts of material. There are several points where you can ensure that equivalent amounts of chromatin are present. Initially, you should start with roughly the same number of cells between the two biological samples (step 1). Once nuclei are isolated, measurement of nucleic acid content prior to MNase digestion (step 16) then permits you to adjust the concentration of chromatin to compensate for any loss that may have occurred during the lysis steps. Nucleic acid content is again measured after elution from the HAP column (step 60), and volumes can be adjusted to ensure that similar amounts of DNA are used in the immunoprecipitation. Finally, an aliquot of the elution from the HAP column (input for the immunoprecipitation) is retained (step 60) for qPCR such that all values obtained from the immunoprecipitated material can be corrected during the data analysis step (step 88) for small variations in the amount of input material.

b) Specificity of immunoprecipitation

It is important to ensure that chromatin containing your locus of interest has not been immunoprecipitated non-specifically. Ideally, this is accomplished by performing a mock IP in parallel using preimmune serum (available if you have prepared the antibody yourself). If preimmune serum is not available, IgG isolated from an animal of the same species from which the antibody was generated is a good alternative. This is prepared in parallel with your specific 
antibody in step 52 (perform steps 47 to 88 in parallel for both test and mock antibodies). In calculating the amount of specific chromatin that is immunoprecipitated with a given antibody (step 88), it is strongly advised to subtract off the amount of chromatin immunoprecipitated with the control antisera/lgG. This will help maximize the signal-to-noise ratio. Note that if multiple ChIPs are performed in parallel, and the antibodies used are generated in different species, it is necessary to carry out a mock IP using IgG from each of those species.

c) Control for pipetting error in $\mathrm{qPCR}$

As qPCR requires extensive pipetting of small volumes, it is advised to perform all analysis of a biological sample in triplicate, and present the data +/standard deviation.

\section{MNase digestion}

In this protocol, chromatin is fragmented using MNase which preferentially cleaves DNA in the internucleosomal regions. We generally establish conditions which provides oligonucleosomes ranging from 1 to 3 nucleosomes in length when observed by ethidium bromide staining after agarose gel electrophoresis (Figure 3A). Using these conditions, we have succeeded in extracting comparable amounts of euchromatin and heterochromatin from nuclei(Figure 2). Since immunoprecipitation of such a population of nucleosomes enriches for the 
longer chromatin fragments (longer nucleosomal arrays have more histones that have the potential to be immunoprecipited), we estimate that this degree of fragmentation provides us with a resolution of approximately $500 \mathrm{bp}$. It should be noted that studies aimed at examining the modifications of histones within the constitutive heterochromatin may require higher concentrations of MNase to obtain similar degrees of resolution, since compacted DNA is more resistant to nuclease digestion. If there are concerns about the resolution of ChIPs at a locus of interest, the average length of the nucleosomal fragments containing a locus of interest can be determined by indirect end-labeling ${ }^{20}$.

\section{Size of chromatin fragments obtained following HAP}

In this protocol, we have used hydroxyapatite chromatography to purify nucleosomal arrays of 1-3 nucleosomes. This technique provides less resolution than N-ChIP protocols which uses a sucrose gradient to isolate mononucleosomes after MNase digestion ${ }^{2}$. However, in developing conditions for these studies, our goal was to obtain the best possible resolution while maximizing probability of a successful outcome. We reasoned that since qPCR amplicons are usually 80-200 bp in length and mononucleosomes are 147-200 bp in length, it can become problematic to design a primer set that will fall within a short fragment without prior detailed knowledge of the positioning of nucleosomes. Furthermore, several studies have demonstrated that nucleosomes shift upon activation of gene expression ${ }^{21}$. Thus, a primer set that is 
designed to work in a single nucleosome could provide erroneous results if one of the primers fails to bind to its target DNA sequence after gene activation. Thus, we believe that the 1-3 nucleosome resolution is best for qPCR based analysis of $\mathrm{N}$-ChIP experiments. On the other hand, mononucleosome resolution is more adapted to N-ChIP-microarray and N-ChIP-Sequencing studies. Thus, for these latter studies, we recommend purification of nucleosomes by HAP chromatography with a further step of mononucleosome isolation by sedimentation on a $5-25 \%$ sucrose gradient ${ }^{2}$.

\section{Primer and probe design}

While many algorithms exist to design qPCR primers, we generally use the PrimerQuest algorithm that is freely available on the Integrated DNA technologies (IDT) web site. In designing a primer/probe set, we usually identify approximately 500 bp of DNA sequence centered over a DNA element of interest. This DNA sequence is then used for a basic search which identifies possible PCR primers/probe pairs for Real-time PCR analysis. Amplicons obtained from your primer sets should range from 80 to $200 \mathrm{bp}$. To ensure specificity of your primers/probe sets, identified sequences should be subject to a blast search to confirm that they recognize a unique sequence within the genome.

\section{General considerations}


Successful completion of this protocol will provide the user with information regarding whether a specific histone post-translational modification exists at nucleosomes present within a specific genomic location. However, enrichment values are not absolute, and must be compared relative to other genomic locations immunoprecipitated with the same antibody. In addition, relative levels of two different modifications at a single genomic position cannot be directly measured by this technique. Thus, to obtain meaningful biological information from these studies, comparisons must be performed by examining multiple genomic locations (spatial), and/or different time points during a biological process (temporal).

\section{MATERIALS}

\section{Reagents:}

Trizma Base (Sigma, cat. no. T6066)

Hepes Potassium Salt - Hepes K+ (Sigma, cat. no. H0527)

Glycerol (Sigma, cat. no. G7757)

Sodium Chloride - NaCl (Sigma, cat. no. S3014)

Potassium Chloride - KCl (Sigma, cat. no. P9541)

Sucrose (Sigma/Fluka, cat. no. 84097)

Magnesium Chloride $-\mathrm{MgCl}_{2} \cdot 6 \mathrm{H}_{2} \mathrm{O}$ (Sigma, cat. no. M2670)

Calcium Chloride $-\mathrm{CaCl}_{2} \cdot 2 \mathrm{H}_{2} \mathrm{O}$ (Sigma cat. no. C3306)

NP-40 Substitute (Sigma/Fluka, cat. no. 74385) Caution! Toxic, wear gloves when handling.

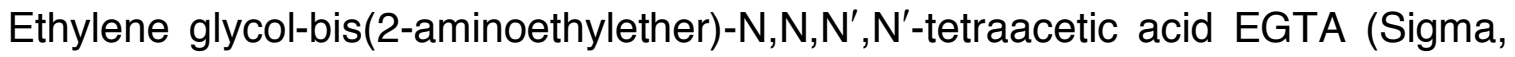
cat. no. E3889)

Ethylenediaminetetraacetic acid disodium salt dihydrate - EDTA (Sigma, cat. no. E5134)

Sodium Phosphate Monobasic - $\mathrm{NaH}_{2} \mathrm{PO}_{4}$ (Sigma, cat. no. S8282)

Sodium Phosphate Dibasic - $\mathrm{Na}_{2} \mathrm{HPO}_{4}$ (Sigma, cat. no. S7907)

Phenylmethanesulfonyl Fluoride - PMSF (Sigma, cat. no. P7626) Caution! Toxic, wear gloves when handling. 
DL-Dithiothreitol - DTT (Sigma, cat. no. D9779)

Sodium Dodecyl Sulfate - SDS (Sigma, cat. no. L4390) Caution! Toxic, wear gloves and mask when weighing powder, and gloves when handling solution.

$\beta$-Glycerophosphate (Sigma/Fluka, cat. no. 50020)

Phosphate Buffered Saline - PBS (Sigma, cat. no. P3813)

Salmon Sperm DNA (Sigma, cat. no. D1626)

Albumin from chicken egg whites (Sigma, cat. no. A5503)

Trichostatin A (Sigma, cat. no. T8552)

RNase A (Sigma, cat. no. R4642)

Proteinase K (Sigma, cat. no. P4850)

Sodium Acetate - NaAc (Sigma, cat. no. S2889)

$\mathrm{EtOH}(99 \%)$ Caution! Flammable, keep away from open flame.

Agarose (Invitrogen, cat. no. 15510-027)

Ethidium Bromide (Sigma, cat. no. E1510)

Glycogen (Fermentas, cat. no. R0561)

Phenol/Chloroform/Isoamyl Alcohol (Sigma, cat. no. P2069) Caution! Toxic, wear gloves when handling.

Chloroform/Isoamyl Alcohol (Sigma, cat. no. C0549) Caution! Toxic, wear gloves when handling.

Micrococcal Nuclease (Sigma, cat. no. N5386)

DNA Ladder - 100 bp (Invitrogen, cat no. 15628-050)

Macro-prep Ceramic Hydroxyapatite Type I $20 \mu \mathrm{m}$ (BioRad, cat. no. 157-0020)

Micro Spin Columns (Nest Group, cat. no. SEM0000)

Dynabeads Protein A (Dynal, cat. no. 100.02)

Dynabeads Protein G (Dynal, cat. no. 100.04)

Siliconized eppendorf tubes (VWR, cat. no. 20170-650)

PCR Tubes (0.1 mL) and caps for RotorGene 6000 (Corbett, cat no. 3001-002)

AmpliTaq Gold with GeneAmp 10X PCR Buffer II kit (Applied Biosystems, cat. no. N808-0249)

dATP, $100 \mathrm{mM}$ Solution (Invitrogen, cat. no. 55082)

dCTP, $100 \mathrm{mM}$ Solution (Invitrogen, cat. no. 55083)

dGTP, $100 \mathrm{mM}$ Solution (Invitrogen, cat. no. 55084)

dTTP, 100 mM Solution (Invitrogen, cat. no. 55085)

Primers and Hydrolysis Probes Set (custom order from Integrated DNA Technologies)

\section{Reagent Set Up}

- PBS - dissolve contents of one pouch in $1 \mathrm{~L}$ of water. Autoclave, and store at $4^{\circ} \mathrm{C}$ for up to 6 months.

- NP-40 Substitute (10\% vol/vol) - $10 \mathrm{~mL}$ of NP-40 Substitute; make up to $100 \mathrm{~mL}$ with water. Store at RT for up to 6 months.

- SDS (10\% wt/vol) - $10 \mathrm{~g}$ of SDS; make up to $100 \mathrm{~mL}$ with water. Caution! Store at RT for up to 6 months. 
- PMSF (200 mM) - $1.74 \mathrm{~g}$ of PMSF; make up to $50 \mathrm{~mL}$ with EtOH. Caution! Store at RT for up to 1 month.

- DTT (1 M) - $3.09 \mathrm{~g}$ of DTT; make up to $20 \mathrm{~mL}$ with $10 \mathrm{mM}$ Sodium acetate $\mathrm{pH}$ 5.2. Filter sterilize, aliquot and store at $-20^{\circ} \mathrm{C}$ for years.

- Tris pH $7.4(10 \mathrm{mM})-121.2 \mathrm{mg}$ of Trizma Base, $\mathrm{pH}$ to 7.4 with $\mathrm{HCl}$; make up to $100 \mathrm{~mL}$ with water. Autoclave, and store at RT for up to 6 months.

- TE - $606 \mathrm{mg}$ of Trizma Base (50 mM final), $37 \mathrm{mg}$ of EDTA (1mM final); adjust $\mathrm{pH}$ to 8.0 with $\mathrm{HCl}$, and make up to $100 \mathrm{~mL}$ with water. Autoclave, and store at RT for up to 6 months.

- STE (0.1 M) - $606 \mathrm{mg}$ of Trizma Base (50 mM final), $37 \mathrm{mg}$ of EDTA (1mM final), $584 \mathrm{mg}$ of $\mathrm{NaCl}(100 \mathrm{mM}$ final); make up to $100 \mathrm{~mL}$ with water. Autoclave, and store at RT for up to 6 months.

- Proteinase K $(10 \mathrm{mg} / \mathrm{mL})$ - $100 \mathrm{mg}$ of proteinase $\mathrm{K}$; make up to $10 \mathrm{~mL}$ with sterile TE pH 8 , aliquot, and store at $-20^{\circ} \mathrm{C}$ for several years.

- Sodium Acetate pH $5.2(3 \mathrm{M})-24.61 \mathrm{~g}$ of sodium acetate; adjust pH to 5.2 with glacial acetic acid, and make up to $100 \mathrm{~mL}$ with water. Autoclave, and store at RT for up to 6 months.

- Albumin (10 mg/mL) - $100 \mathrm{mg}$ of ovalbumin; make up to $10 \mathrm{~mL}$ with ChIP Buffer 1. Filter sterilize, and store at $4^{\circ} \mathrm{C}$ for up to 1 month.

- Trichostatin $\mathbf{A}(1 \mathrm{mM})-1 \mathrm{mg}$ of trichostatin A, make up to $3.3 \mathrm{~mL}$ with ethanol, aliquot, and store at $-20^{\circ} \mathrm{C}$ for several years.

- $\mathrm{NaCl}(5 \mathrm{M})-29.22 \mathrm{~g}$ of $\mathrm{NaCl}$; make up to $100 \mathrm{~mL}$ with water. Autoclave, and store at RT for several years.

- $\mathrm{Na}_{2} \mathrm{HPO}_{4}(1 \mathrm{M})$ - $141.96 \mathrm{~g}$ of $\mathrm{Na}_{2} \mathrm{HPO}_{4}$; make up to $1 \mathrm{~L}$ with water. Autoclave, and store at RT for several years.

- $\mathrm{NaH}_{2} \mathrm{PO}_{4}(\mathbf{M} \mathrm{M})$ - $119.98 \mathrm{~g}$ of $\mathrm{NaH}_{2} \mathrm{PO}_{4}$; make up to $1 \mathrm{~L}$ with water. Autoclave, and store at RT for several years.

- Buffer $\mathbf{N}-182 \mathrm{mg}$ of Trizma base (15 mM final), $87 \mathrm{mg} \mathrm{NaCl}$ (15 mM final), $447 \mathrm{mg}$ of $\mathrm{KCl}(60 \mathrm{mM}$ final); $8.56 \mathrm{~g}$ of sucrose (250 mM final), $102 \mathrm{mg}$ of $\mathrm{MgCl}_{2} \cdot 6 \mathrm{H}_{2} \mathrm{O}$ (5 mM final), and $15 \mathrm{mg}$ of $\mathrm{CaCl}_{2} \cdot 2 \mathrm{H}_{2} \mathrm{O}$ ( $1 \mathrm{mM}$ final); adjust $\mathrm{pH}$ to 7.5 with hydrochloric acid, and make up to $100 \mathrm{~mL}$ with water. Filter sterilize, and store at $4^{\circ} \mathrm{C}$ for up to 1 week. At the time of use, add Trichostatin A, $D T T, \beta$-glycerophosphate and PMSF to a final concentration of $1 \mu \mathrm{M}, 1 \mathrm{mM}$, $10 \mathrm{mM}$ and $200 \mu \mathrm{M}$ respectively.

- 2x Lysis Buffer - $182 \mathrm{mg}$ of Trizma base (15 mM final), $87 \mathrm{mg} \mathrm{NaCl}$ (15 mM final), $447 \mathrm{mg}$ of $\mathrm{KCl}(60 \mathrm{mM}$ final); $8.56 \mathrm{~g}$ of sucrose (250 mM final), $102 \mathrm{mg}$ of $\mathrm{MgCl}_{2} \cdot 6 \mathrm{H}_{2} \mathrm{O}\left(5 \mathrm{mM}\right.$ final), $15 \mathrm{mg}$ of $\mathrm{CaCl}_{2} \cdot 2 \mathrm{H}_{2} \mathrm{O}$ (1 mM final), and $6 \mathrm{~mL}$ of $10 \%(\mathrm{vol} / \mathrm{vol}) \mathrm{NP}-40$ Substitute $(0.6 \% \mathrm{vol} / \mathrm{vol}$ final); adjust $\mathrm{pH}$ to 7.5 with hydrochloric acid, and make up to $100 \mathrm{~mL}$ with water. Filter sterilize, and store at $4^{\circ} \mathrm{C}$ for up to 1 week. At the time of use, add Trichostatin A, DTT, $\beta$ glycerophosphate and PMSF to a final concentration of $1 \mu \mathrm{M}, 1 \mathrm{mM}, 10 \mathrm{mM}$, and $200 \mu \mathrm{M}$ respectively.

- EX50 - 2.76 g of Hepes $\mathrm{K}^{+}, 2.92 \mathrm{~g}$ of $\mathrm{NaCl}, 304 \mathrm{mg}$ of $\mathrm{MgCl}_{2} \cdot 6 \mathrm{H}_{2} \mathrm{O}, 190 \mathrm{mg}$ of EGTA, $3.06 \mathrm{~g}$ of $\beta$-Glycerophosphate, and $100 \mathrm{~mL}$ of glycerol. adjust $\mathrm{pH}$ to 
7.6 with hydrochloric acid, and make up to $1 \mathrm{~L}$ with water. Autoclave, and store at $4^{\circ} \mathrm{C}$ for up to 6 months. At the time of use, add DTT and PMSF to a final concentration of $1 \mathrm{mM}$ and $200 \mu \mathrm{M}$ respectively.

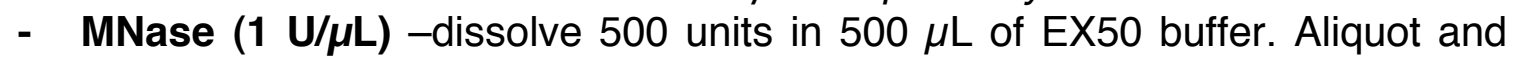
stored at $-80^{\circ} \mathrm{C}$ for up to 1 year.

- 10x MNase Stop Buffer - $4.18 \mathrm{~g}$ of EGTA (110 mM final), and $4.09 \mathrm{~g}$ of EDTA (110 mM final); make up to $100 \mathrm{~mL}$ with water. Autoclave, and store at RT for up to 6 months.

- HAP Buffer 1 - $684 \mu \mathrm{L}$ of $1 \mathrm{M} \mathrm{Na}_{2} \mathrm{HPO}_{4}, 316 \mu \mathrm{L}$ of $1 \mathrm{M} \mathrm{NaH}_{2} \mathrm{PO}_{4}$ (5 mM $\mathrm{NaPO}_{4}, \mathrm{pH} 7.2$ final), $7.01 \mathrm{~g}$ of $\mathrm{NaCl}(600 \mathrm{mM}$ final), and $400 \mu \mathrm{L}$ of $0.5 \mathrm{M}$ EDTA ( $1 \mathrm{mM}$ final); make up to $200 \mathrm{~mL}$ with water. Autoclave, and store at $4^{\circ} \mathrm{C}$ for up to 6 months. At the time of use, add Trichostatin $A, \beta$ glycerophosphate, and PMSF to a final concentration of $1 \mu \mathrm{M}, 10 \mathrm{mM}$, and $200 \mu \mathrm{M}$ respectively.

- HAP Buffer 2 - $684 \mu \mathrm{L}$ of $1 \mathrm{M} \mathrm{Na}_{2} \mathrm{HPO}_{4}, 316 \mu \mathrm{L}$ of $1 \mathrm{M} \mathrm{NaH}_{2} \mathrm{PO}_{4}(5 \mathrm{mM}$ $\mathrm{NaPO}_{4}, \mathrm{pH} 7.2$ final), $1.17 \mathrm{~g}$ of $\mathrm{NaCl}(100 \mathrm{mM}$ final), and $400 \mu \mathrm{L}$ of $0.5 \mathrm{M}$ EDTA ( $1 \mathrm{mM}$ final); make up to $200 \mathrm{~mL}$ with water. Autoclave, and store at $4^{\circ} \mathrm{C}$ for up to 6 months. At the time of use, add PMSF to a final concentration of $200 \mu \mathrm{M}$.

- HAP Elution Buffer - $68 \mathrm{~mL}$ of $1 \mathrm{M} \mathrm{Na}_{2} \mathrm{HPO}_{4}, 32 \mathrm{~mL}$ of $1 \mathrm{M} \mathrm{NaH}_{2} \mathrm{PO}_{4}(500$ $\mathrm{mM} \mathrm{NaPO}_{4}, \mathrm{pH} 7.2$ final), $1.17 \mathrm{~g}$ of $\mathrm{NaCl}(100 \mathrm{mM}$ final), and $400 \mu \mathrm{L}$ of $0.5 \mathrm{M}$ EDTA ( $1 \mathrm{mM}$ final); make up to $200 \mathrm{~mL}$ with water. Autoclave, and store at $4^{\circ} \mathrm{C}$ for up to 6 months. At the time of use, add PMSF to a final concentration of $200 \mu \mathrm{M}$.

- 10x Tris-Glycine Buffer - $288 \mathrm{~g}$ of Glycine, and $60.6 \mathrm{~g}$ of Trizma Base; make up to $2 \mathrm{~L}$ with water. Store at $\mathrm{RT}$ for up to a year.

- ChIP Buffer 1 - $303 \mathrm{mg}$ of Trizma Base (25 mM final), $102 \mathrm{mg}$ of $\mathrm{MgCl}_{2} \cdot 6 \mathrm{H}_{2} \mathrm{O}$ (5 mM final), $746 \mathrm{mg}$ of $\mathrm{KCl}(100 \mathrm{mM}$ final), $10 \mathrm{~mL}$ of Glycerol (10\% vol/vol final), $1 \mathrm{~mL}$ of $10 \%(\mathrm{vol} / \mathrm{vol}) \mathrm{NP}-40$ Substitute $(0.1 \% \mathrm{vol} / \mathrm{vol}$ final); make up to $100 \mathrm{~mL}$ with water. Autoclave and store at $4^{\circ} \mathrm{C}$ for up to 6 months. At the time of use, add PMSF to a final concentration of $200 \mu \mathrm{M}$.

- ChIP Buffer 2 - $303 \mathrm{mg}$ of Trizma Base (25 mM final), $102 \mathrm{mg}$ of $\mathrm{MgCl}_{2} \cdot 6 \mathrm{H}_{2} \mathrm{O}$ (5 mM final), $2.24 \mathrm{~g}$ of $\mathrm{KCl}(300 \mathrm{mM}$ final), $10 \mathrm{~mL}$ of Glycerol (10\% vol/vol final), $1 \mathrm{~mL}$ of $10 \%(\mathrm{vol} / \mathrm{vol}) \mathrm{NP}-40$ Substitute $(0.1 \% \mathrm{vol} / \mathrm{vol}$ final); make up to $100 \mathrm{~mL}$ with water. Autoclave and store at $4^{\circ} \mathrm{C}$ for up to 6 months. At the time of use, add PMSF to a final concentration of $200 \mu \mathrm{M}$.

- ChIP Elution Buffer - $606 \mathrm{mg}$ of Trizma Base (50 mM final), $37 \mathrm{mg}$ of EDTA (1 mM final), $10 \mathrm{~mL}$ of $10 \%$ (wt/vol) SDS (1\% wt/vol final); make up to $100 \mathrm{~mL}$ with water. Filter sterilize, and store at $4^{\circ} \mathrm{C}$ for up to 1 month.

- Sheared Salmon Spearm DNA (10 $\mathrm{mg} / \mathrm{mL})$ - $1 \mathrm{~g}$ of salmon sperm DNA; make up to $100 \mathrm{~mL}$ with $0.4 \mathrm{M} \mathrm{NaOH}$, and stir overnight in a beaker. Place beaker on a hot plate, and bring to a boil. Continue to boil for 45 minutes. Cool on ice, and neutralize with glacial acetic acid to $\mathrm{pH} 7$. Spin out any debris in benchtop centrifuge at $3725 \mathrm{~g}$ for 30 minutes. Recover supernatant 
and add 2 volumes of $\mathrm{EtOH}$ to precipitate DNA. Spin in benchtop centrifuge at $3725 \mathrm{~g}$ for 30 minutes. Recover pellet and dissolve in TE pH 7.4 at a concentration of $10 \mathrm{mg} / \mathrm{mL}$. Aliquot and store at $-20^{\circ} \mathrm{C}$ for several years.

\section{Equipment:}

Scientific Industries Vortex-Genie (or equivalent)

Eppendorf Biophotometer (or equivalent)

Eppendorf 5424 Microcentrifuge (or equivalent)

Dynal MPC-S Magnetic Bead Concentrator (or equivalent)

Barnstead Thermolyne Labquake Rotator (or equivalent)

Corbett RotorGene 6000 Real Time PCR machine (or equivalent)

Eppendorf Vacufuge Concentrator (or equivalent)

Eppendorf Thermomixer (or equivalent)

Beckman-Coulter Allegra X15R Tabletop Centrifuge (or equivalent)

Alpha Imager HP Gel Documentation System (or equivalent)

BioRad PowerPac Basic Power Supply (or equivalent)

BioRad Mini-Sub Cell GT (or equivalent)

\section{Procedure:}

Isolation of nuclei $\bullet$ Timing $2 \mathrm{~h}$

1 This step can be performed using option A or option B depending on whether you are starting with adherent cells or cells grown in suspension.

A. Adherent cells

i) Starting with approximately $10^{7}$ cells, wash cells twice with $10 \mathrm{~mL}$ of PBS, and aspirate off the solution.

ii) Apply $4 \mathrm{~mL}$ of trypsin to cells and incubate for 5 minutes at $37^{\circ} \mathrm{C}$.

iii) Add $6 \mathrm{~mL}$ of culture medium to the plate, and collect the cells by pipetting up and down for a total of 3 times

iv) Transfer cell suspension to a $15 \mathrm{~mL}$ tube, and spin at $524 \mathrm{~g}$ in a tabletop centrifuge $\left(4^{\circ} \mathrm{C}\right)$. 
v) Aspirate supernatant, and discard.

B. Suspension cells

i) Transfer approximately $10^{7}$ cells to a $15 \mathrm{~mL}$ tube, and spin at $524 \mathrm{~g}$ in a tabletop centrifuge $\left(4^{\circ} \mathrm{C}\right)$.

ii) Aspirate supernatant, and discard.

2 Resuspend cells in $10 \mathrm{ml}$ of ice-cold PBS containing $200 \mu \mathrm{M}$ PMSF, $1 \mu \mathrm{M}$ Trichostatin A, and $10 \mathrm{mM} \beta$-glycerophosphate. Try to obtain a single cell suspension (no visible clumps). Spin at $524 \mathrm{~g}$ in a tabletop centrifuge $\left(4^{\circ} \mathrm{C}\right)$. Aspirate supernatant, and discard. Repeat this wash once more.

CRITICAL STEP: It is usually sufficient to look at the cells with the naked eye to determine whether there are any visible clumps present. If unsure, an aliquot of the cells can be examined under a microscope. If unable to disrupt the clumps, a short pulse of sonication can be attempted to separate aggregates.

3 Resuspend cells in $5 \mathrm{ml}$ of ice-cold Buffer $\mathrm{N}$ to obtain a single cell suspension (no visible clumps). Spin at $524 g$ in a tabletop centrifuge $\left(4^{\circ} \mathrm{C}\right)$. Aspirate supernatant. Repeat once more.

4 Resuspend cells in $1 \mathrm{~mL}$ of ice-cold Buffer $\mathrm{N}$ by pipetting up and down using a P-1000. 
CRITICAL STEP: Single cell suspensions must be obtained at this point (ie. no clumps visible to the naked eye). If this is not obtained, lysis of the cells will not be homogeneous. If clumping of the cells occurs, try subjecting cell suspension to a short pulse of sonication. If this does not work, prepare new buffer $\mathrm{N}$ and start procedure over.

5 Once single cell suspensions are obtained, commence vortexing at low speed (i.e. Vortex genie speed 3 on a scale of 10) and simultaneously add dropwise 1 $\mathrm{mL}$ of ice-cold 2X Lysis Buffer.

6 Incubate on ice for 10 minutes to complete cell lysis.

7 Spin at $524 g$ in a tabletop centrifuge $\left(4^{\circ} \mathrm{C}\right)$. Remove supernatant by aspiration and discard.

\section{? Troubleshooting}

CRITICAL STEP: At this point, the nuclear pellet should be white (as opposed to off-white/beige for the cellular pellet). A final concentration of $0.3 \%$ (vol/vol) NP40 is sufficient to break open the different cell lines we have tested. However, some cell lines may be resistant to this concentration of detergent. If your pellet does not become white, resuspend the pellet in buffer $\mathrm{N}$, and examine an aliquot under a microscope. If the majority of the cells are not lysed, prepare a new $2 \mathrm{X}$ Lysis Buffer with a slightly higher concentration of NP40, and repeat steps 5 to 7 . 
8 Resuspend nuclei in $500 \mu \mathrm{L}$ of ice-cold Buffer $\mathrm{N}$ by pipetting up and down using a $\mathrm{P}-1000$.

9 Transfer nuclei to a siliconized eppendorf tube and keep on ice.

10 Add a second $500 \mu \mathrm{L}$ aliquot of ice-cold buffer $\mathrm{N}$ to the $15 \mathrm{~mL}$ tube (from Step 8) in order to wash out any remaining nuclei.

11 Combine with the first $500 \mu$ l of nuclei (from Step 9). The volume is now $1 \mathrm{~mL}$.

12 Spin nuclei at $600 \mathrm{~g}$ for 5 minutes in a microcentrifuge at $4^{\circ} \mathrm{C}$. Remove supernatant by aspiration and discard.

13 Resuspend nuclei again in $1 \mathrm{~mL}$ of buffer $\mathrm{N}$ by pipetting up and down using a P-1000.

CRITICAL STEP: Again try to obtain single nuclei suspensions (no visible clumps).

14 Spin nuclei at $600 \mathrm{~g}$ for 5 minutes in a microcentrifuge at $4^{\circ} \mathrm{C}$. Remove supernatant by aspiration and discard. 
15 Resuspend nuclei in $100 \mu \mathrm{L}$ of buffer $\mathrm{N}$.

16 Determine the relative nucleic acid content of the sample by spectrophotometry. This can be done by taking $4 \mu \mathrm{L}$ of the nuclei suspension, and placing in $400 \mu \mathrm{L}$ of $2 \mathrm{M} \mathrm{NaCl}$. Make sure to blank the spectrophotometer using $4 \mu \mathrm{L}$ of Buffer $\mathrm{N}$ in $400 \mu \mathrm{L}$ of $2 \mathrm{M} \mathrm{NaCl}$. Read the optical density at $260 \mathrm{~nm}$ using a quartz cuvette. The nucleic acid concentration will be OD260 × $50 \mathrm{ng} / \mu \mathrm{L}$ x 100 (dilution factor) (See Table 1 for an example).

CRITICAL STEP: The desired concentration is approximately $1 \mu \mathrm{g} / \mu \mathrm{L}$. If the concentration is greater than $1 \mu \mathrm{g} / \mu \mathrm{L}$, dilute the sample using buffer $\mathrm{N}$. If the concentration is too low (less than $0.8 \mu \mathrm{g} / \mu \mathrm{L}$ ), centrifuge the nuclei as described in step 14 and resuspend in a smaller volume.

Fragmentation of chromatin using micrococcal nuclease (MNase) $\bullet$ Timing $15 \min$

17 Dilute the stock solution of MNase ( $1 \mathrm{U} / \mu \mathrm{L})$ stock 1 in 20 using EX50 buffer to a final concentration of $0.05 \mathrm{U} / \mu \mathrm{L}$.

CRITICAL STEP: Use a filtered tip to pipette concentrated MNase so that the pipette does not become contaminated with the nuclease for future experiments.

18 Add appropriate amount of MNase (see below) to $100 \mu \mathrm{L}$ of single nuclei suspension 
CRITICAL STEP: The concentration of MNase to use in your digestion has to be determined empirically. We usually find good results using 50 milliunits per $40 \mu \mathrm{g}$ of nucleic acid.

CRITICAL STEP: Ensure nuclei are not clumped before adding MNase; if nuclei clump after resuspension, access of the MNase to chromatin will not be even, which might result in some DNA being of high molecular weight, and a loss of resolution in your ChIP studies.

19 Incubate for 10 minutes in a waterbath at $37^{\circ} \mathrm{C}$.

20 Stop the reaction by adding $11 \mu \mathrm{L}\left(1 / 10^{\text {th }}\right.$ volume $)$ of MNase stop buffer, and place on ice.

21 Take a $5 \mu \mathrm{L}$ aliquot of sample to visualize nucleosomal arrays on an agarose gel in steps 36-45 (this sample corresponds to the Digested Nuclei in Figure 3A). CRITICAL STEP: Nucleosomes should be run on a gel to determine the average nucleosome length as this is what determines the resolution of your ChIP studies.

\section{Purification of the nucleosomes using hydroxyapatite $\bullet$ Timing 30 min}

22 Lyse nuclei by adding $15 \mu \mathrm{L}$ of $5 \mathrm{M} \mathrm{NaCl}$ to the $111 \mu \mathrm{L}$ of MNase digested sample (from Step 20). 
23 Add $200 \mu \mathrm{L}$ of HAP Buffer 1, as well as $66 \mathrm{mg}$ of hydroxyapatite resin per 100 $\mu \mathrm{g}$ of DNA, vortex thoroughly and incubate on a rotator for 10 minutes at $4^{\circ} \mathrm{C}$.

24 Transfer the chromatin:hydroxyapatite slurry to a Microspin column.

25 Place the Microspin column in an eppendorf tube. Spin in microfuge for 1 $\min$ at $600 \mathrm{~g}\left(4^{\circ} \mathrm{C}\right)$.

\section{? Troubleshooting}

26 Keep a $5 \mu \mathrm{L}$ aliquot of the column flow-through to visualize nucleosomal arrays on an agarose gel in steps $36-45$ (this sample corresponds to the HAP FT in Figure 3A). The remaining flow-through can be discarded.

27 Add $200 \mu \mathrm{L}$ of HAP Buffer 1 to eppendorf tube (that contained the chromatin:hydroxyapatite slurry in step 23) to rinse it out, and then transfer onto the same Microspin column.

$28 \mathrm{Spin}$ column again in microfuge for $1 \mathrm{~min}$ at $600 \mathrm{~g}\left(4^{\circ} \mathrm{C}\right)$. Keep a $5 \mu \mathrm{L}$ aliquot of wash to visualize nucleosomal arrays on an agarose gel in steps 36-45 (this sample corresponds to the HAP Wash600 in Figure 3A), and discard the remaining wash. 
29 Repeat wash (steps 27 and 28) three more times with $200 \mu \mathrm{L}$ of HAP buffer 2 (4 washes total). Discard washes.

30 Add $200 \mu \mathrm{L}$ of HAP Buffer 2 to the same column.

31 Spin column again in microfuge for $1 \mathrm{~min}$ at $600 \mathrm{~g}\left(4^{\circ} \mathrm{C}\right)$. Keep a $5 \mu \mathrm{L}$ aliquot of wash to visualize nucleosomal arrays on an agarose gel in steps 36-45 (this sample corresponds to the HAP Wash 100 in Figure 3A), and discard the remaining wash.

32 Repeat wash (step 30 and 31) three more times with $200 \mu \mathrm{L}$ of HAP buffer 2 (4 washes total). Discard washes.

33 Add $100 \mu \mathrm{L}$ of HAP Elution Buffer to the same column. Transfer column to a fresh eppendorf tube.

34 Spin column again in microfuge for $1 \mathrm{~min}$ at $600 \mathrm{~g}\left(4^{\circ} \mathrm{C}\right)$. Keep the elution on ice, and take a $5 \mu \mathrm{L}$ aliquot of all elutions for visualization of nucleosomal arrays on an agarose gel in steps $36-45$ (this sample corresponds to the Elution 1 in Figure 3A). 
35 Repeat steps 33 and 34 two more times with $100 \mu \mathrm{L}$ of HAP Elution buffer using a fresh eppendorf tube for each elution (3 Elutions total). Keep the elutions on ice, and take a $5 \mu \mathrm{L}$ aliquot of all elutions for visualization of nucleosomal arrays on an agarose gel in steps $36-45$ (this sample corresponds to the Elution 2, and Elution 3 in Figure $3 \mathrm{~A}$ ).

36 Dilute $5 \mu \mathrm{L}$ aliquots saved from steps $21,26,28,31,34$ and 35 to $200 \mu \mathrm{L}$ with ChIP elution buffer, add $1 \mu \mathrm{L}$ of proteinase $\mathrm{K}(10 \mathrm{mg} / \mathrm{mL})$, and incubate for 30 $\min$ at $42^{\circ} \mathrm{C}$.

37 Add $200 \mu \mathrm{L}$ of phenol/chloroform, and spin for 5 minutes at $9300 \mathrm{~g}$ in microcentrifuge.

38 Transfer the aqueous (top) layer to a second tube containing $200 \mu \mathrm{L}$ of phenol/ chloroform/isoamyl alcohol, vortex, and spin for 5 minutes at 9,300 g.

39 Transfer $180 \mu \mathrm{L}$ of aqueous (top) layer to fresh tube. Add $20 \mu \mathrm{L}$ of $3 \mathrm{M}$ sodium acetate, $1 \mu \mathrm{L}$ of glycogen, and $500 \mu \mathrm{L}$ of $\mathrm{EtOH}$. Vortex and place at $-80^{\circ} \mathrm{C}$ for 30 $\min$.

40 Spin for 15 minutes at $15,800 \mathrm{~g}$ at $4^{\circ} \mathrm{C}$. Remove the supernatant by aspiration and discard. 
41 Add $500 \mu \mathrm{L}$ of $70 \% \mathrm{EtOH}$ to the pellet, vortex and spin at $15,800 \mathrm{~g}$ for $5 \mathrm{~min}$ at $4^{\circ} \mathrm{C}$. Remove the supernatant by aspiration and discard.

42 Dry pellet for 5 minutes in a speed vac without heat (or air dry for 15 minutes).

43 Redissolve pellet in $5 \mu \mathrm{L}$ of $0.1 \mathrm{M} \mathrm{STE}$. Add $1 \mu \mathrm{L}$ of $6 \mathrm{x}$ loading dye.

44 Run DNA samples on a $1.2 \%$ agarose in $1 x$ Tris-Glycine gel at a constant rate of 5-7 volts/cm. Remember to run a $100 \mathrm{bp}$ molecular weight marker along side the digested chromatin.

45 Stain gel with ethidium bromide, and visualize using an ultraviolet transilluminator, or gel documentation system. A sample gel is shown in Figure 3A.

\section{? Troubleshooting}

46 Pool Elution 1 and Elution 2 (200 $\mu \mathrm{L}$ total after pooling) CRITICAL STEP: Most of the chromatin should appear in Elutions 1 and 2, with a small amount in Elution $3(<5 \%)$. We generally pool elution 1 and 2 for proceeding in Step 60. 
Immunoprecipitation of modified nucleosomes • Timing $20 \mathrm{~h}$

47 Vortex the Protein A-Dynabeads thoroughly to resuspend before pipetting. For each immunoprecipitation, pipet $20 \mu \mathrm{l}$ of Dynabeads into a siliconized eppendorf tube.

CRITICAL STEP: Do not forget to prepare mock antibody for immunoprecipitation in parallel to control for non-specific interactions.

CRITICAL STEP: Protein G Dynabeads should be used instead of Protein A Dynabeads if the antibody of interest is a monoclonal antibody of the mouse lgG1 or lgG3 subtypes .

48 Place the tube on the magnet for $1 \mathrm{~min}$, and then pipette off (discard) the supernatant.

49 Remove the tube from the magnet, add $1 \mathrm{~mL}$ of ChIP Buffer 1, vortex briefly.

50 Place the tube on the magnet for $1 \mathrm{~min}$, and then pipette off (discard) the supernatant.

51 Repeat the washing steps 49 and 50 once with $1 \mathrm{~mL}$ of ChIP Buffer 1, and discard the supernatant. 
52 In a separate tube, dilute the required amount of antibody $(\sim 5 \mu \mathrm{g})$ in ChIP Buffer 1 to obtain $100 \mu \mathrm{l}$ final.

53 Transfer diluted antibody obtained in step 52 to the washed beads obtained in step 51 .

54 Agitate for $1 \mathrm{hr}$ at $1400 \mathrm{rpm}$ in an Eppendorf Thermomixer $\left(22^{\circ} \mathrm{C}\right)$.

55 Place the tube on magnet for $1 \mathrm{~min}$ and then pipet out the supernatant (note: supernatant still contains a significant amount of free antibody and can be saved for future western blotting).

56 Remove the tube from the magnet, add $1 \mathrm{~mL}$ of ChIP Buffer 1, vortex briefly.

57 Place the tube on the magnet for $1 \mathrm{~min}$, and then pipette off (discard) the supernatant.

58 Repeat the wash with ChIP Buffer 1 (steps 56 and 57) once. Keep the beads on ice in the presence of ChIP Buffer 1 until ready to proceed with step 60.

CRITICAL STEP In the interest of time, Steps 47 to 58 (binding antibody to beads) can be performed prior (or during) the isolation of nuclei (steps 1-21). 
59 Place the tube on the magnet for $1 \mathrm{~min}$, and then pipette off (discard) the supernatant.

60 Dilute $180 \mu \mathrm{L}$ of chromatin (180 $\mu \mathrm{L}$ of the $200 \mu \mathrm{L}$ obtained in step 46) with 2 $\mathrm{mL}$ of ice-cold ChIP Buffer 1 in order to reduce $\mathrm{NaPO}_{4}$ concentration. Add $2 \mu \mathrm{L}$ of sheared salmon sperm DNA (10 $\mu \mathrm{g} / \mathrm{mL}$ final) and $200 \mu \mathrm{L}$ of $10 \mu \mathrm{g} / \mu \mathrm{L}$ ovalbumin ( $1 \mu \mathrm{g} / \mu \mathrm{L}$ final). Note: This is enough chromatin for 4 different antibodies.

CRITICAL STEP: Remember to keep $50 \mu \mathrm{L}$ of the $2 \mathrm{~mL}$ of diluted chromatin to use as the input control during qPCR analysis on immunoprecipitated DNA. This $50 \mu \mathrm{L}$ sample should be further diluted to $400 \mu \mathrm{L}$ final using $350 \mu \mathrm{L}$ of ChIP Elution buffer, and subjected to the same purification as the immunoprecipitated DNA (outlined in steps 75 to 83 ).

CRITICAL STEP: If multiple chromatin samples are being studied in parallel, ensure that the amount of chromatin used in each immunoprecipitation is similar by measuring $\mathrm{OD}_{260}$. Take $4 \mu \mathrm{L}$ of the HAP elution, and place in $400 \mu \mathrm{L}$ of $2 \mathrm{M}$ $\mathrm{NaCl}$. Make sure to blank the spectrophotometer using $4 \mu \mathrm{L}$ of HAP Elution Buffer in $400 \mu \mathrm{L}$ of $2 \mathrm{M} \mathrm{NaCl}$. Read the optical density at $260 \mathrm{~nm}$ using a quartz cuvette. The nucleic acid concentration will be $\mathrm{OD}_{260} \times 50 \mathrm{ng} / \mu \mathrm{L} \times 100$ (dilution factor). Adjust volumes with HAP Elution buffer as necessary to ensure that approximately the same amount of chromatin is used in each immunoprecipitation. 
61 Transfer $500 \mu \mathrm{L}(\sim 10 \mu \mathrm{g})$ of chromatin (from step 60$)$ into $20 \mu \mathrm{L}$ of beads that have been previously coated with the antibody of your choice (see Step 47-59). Vortex briefly.

CRITICAL STEP: Do not use too much chromatin as the antibody should not be limiting in a ChIP study. If the concentration of the chromatin is greater than 20 $\mu \mathrm{g} / \mathrm{mL}$, dilute to this concentration with ChIP buffer 1 .

62 Rotate tubes overnight at $4^{\circ} \mathrm{C}$ using a Labquake rotator.

-Pause Point: Chromatin should incubate with antibody for 6-20 h

63 Place the tube on the magnet for $1 \mathrm{~min}$ and pipet off (discard) the supernatant.

64 Remove the tube from the magnet, add $1 \mathrm{~mL}$ of ice-cold ChIP Buffer 2 to the beads and vortex briefly.

65 Rotate in Labquake rotator for $10 \mathrm{~min}$. at $4^{\circ} \mathrm{C}$.

66 Place the tube on the magnet for $1 \mathrm{~min}$, and then pipette off (discard) the supernatant. 
67 Repeat the washing steps 64 to 66 twice with ice-cold ChIP Buffer 2, and discard the supernatants.

68 Add $1 \mathrm{~mL}$ of ice-cold ChIP Buffer 1 to the beads, vortex briefly.

69 Place the tube on the magnet for $1 \mathrm{~min}$, and then pipette off (discard) the supernatant.

70 Add $1 \mathrm{~mL}$ of ice-cold TE Buffer to the beads, vortex briefly.

71 Place the tube on the magnet for $1 \mathrm{~min}$, and then pipette off (discard) the supernatant.

72 Add $200 \mu \mathrm{L}$ of ChIP Elution Buffer to beads. Mix for 10 min at $1400 \mathrm{rpm}$ using the Eppendorf Thermomixer $\left(65^{\circ} \mathrm{C}\right)$.

73 Place on the magnet for $1 \mathrm{~min}$, pipet out the supernatant into a fresh siliconized eppendorf tube.

74 Repeat this elution step once with $200 \mu \mathrm{L}$ of ChIP Elution Buffer and combine both supernatants. The final elution volume is now $400 \mu \mathrm{L}$. 
75 In the elution tube, add $17 \mu \mathrm{L}$ of $5 \mathrm{M} \mathrm{NaCl}(0.2 \mathrm{M}$ final) and $2 \mu \mathrm{L}$ of RNase $\mathrm{A}$ (DNase-free). Incubate at $65^{\circ} \mathrm{C}$ for $45 \mathrm{~min}$.

76 In the elution tube, add $9 \mu \mathrm{L}$ of $0.5 \mathrm{M}$ EDTA (10 mM final) and $2 \mu \mathrm{L}$ of 10 $\mathrm{mg} / \mathrm{mL}$ proteinase $\mathrm{K}\left(50 \mu \mathrm{g} / \mathrm{mL}\right.$ final). Incubate at $42^{\circ} \mathrm{C}$ for $2 \mathrm{~h}$.

77 Add $400 \mu \mathrm{L}$ of phenol/chloroform/isoamyl alcohol, vortex, and spin for 5 minutes at 9,300g in microcentrifuge. Discard the organic (lower) layer.

78 Transfer the aqueous (top) layer to a second eppendorf tube containing 400 $\mu \mathrm{L}$ of chloroform/isoamyl alcohol, vortex, and spin for 5 minutes at 9,300g. Discard the organic (lower) layer.

79 Transfer $360 \mu \mathrm{L}$ of aqueous (top) layer to fresh eppendorf tube. Add $40 \mu \mathrm{L}$ of $3 \mathrm{M}$ sodium acetate, $1 \mu \mathrm{L}$ of glycogen, and $1 \mathrm{~mL}$ of EtOH. Place at $-80^{\circ} \mathrm{C}$ for 30 $\min$.

80 Spin for 15 minutes at $15,800 \mathrm{~g}$ for 15 minutes at $4^{\circ} \mathrm{C}$. Remove the supernatant by aspiration and discard.

81 Add $500 \mu \mathrm{L}$ of $70 \% \mathrm{EtOH}$ to the pellet, vortex and spin at $15,800 \mathrm{~g}$ for 5 minutes at $4^{\circ} \mathrm{C}$. Remove the supernatant by aspiration and discard. 
82 Dry pellet for 5 minutes in a speed vac without heat (or air dry for 15 minutes).

83 Redissolve pellet in $200 \mu \mathrm{L}$ of $10 \mathrm{mM}$ Tris $\mathrm{pH} 7.4$. This amount of precipitated DNA should be sufficient to analyze up to 20 genomic locations in triplicate.

-Pause Point: Purified DNA can be stored at $-20^{\circ} \mathrm{C}$ for 6 months or at $-80^{\circ} \mathrm{C}$ for several years.

qPCR analysis of DNA associated with modified histones $\bullet$ Timing $3 \mathrm{~h}$

84 Primers and probes can be designed against specific DNA sequences using the PrimerQuest algorithm available on the IDT web site (http://www.idtdna.com/Scitools/Applications/Primerquest/). We prefer the hydrolysis probe technology for qPCR using a probe labeled with 6carboxyfluorescein (6-FAM) at the 5'-end and Black Hole Quencher 1 (BHQ1) at the 3' end.

85 Set up qPCR by preparing enough master mix for your number of samples plus a little extra to control for pipetting error. A sample master mix for 69 samples is provided in Table 2. One master mix must be prepared for each hydrolysis probe/primer sets (ie. for each genomic position you wish to study), and is pipetted into the PCR tubes. 
CRITICAL STEP: Pipette carefully since small differences could result in large error bars.

86 An aliquot $(5 \mu \mathrm{L})$ of the elutions from the immunoprecipitation (obtained in Step 83) is then pipetted into the tubes containing the master mix. Each elution should be analyzed in triplicate.

87 A series of qPCR should also be performed on a serial dilution of genomic DNA (50 ng to $16 \mathrm{pg}$ ) using the hydrolysis probe/primer set to prepare a standard curve. Genomic DNA is prepared from the cell line of interest using standard procedures $^{22}$. A sample experiment setup using two biological samples (A and B), studied using 3 different antibodies that is analysed with a single hydrolysis probe/primer set is provided in Table 3.

CRITICAL STEP: Pipette carefully since small differences could result in large error bars.

88 To calculate the relative enrichment of the genomic region during your immunoprecipitation, subtract the value obtained in your mock ChIP from the value obtained from your test antibody ChIP. This value can then be divided by the value obtained for your input material to determine the relative enrichment of a histone modification at a single genomic location.

\section{? Troubleshooting}




\section{TIMING (Total procedure requires approximately 1.5 days)}

1. Isolation of nuclei (Steps 1-16) takes approximately $2 \mathrm{~h}$.

\section{Fragmentation of chromatin using MNase (Steps 17-21) takes} approximately $15 \mathrm{~min}$.

3. Purification of nucleosomes using hydroxyapatite (Steps 22-46) takes approximately $30 \mathrm{~min}$ if the purification is to be examined by agarose gel electrophoresis at a future time. If the purification is to be examined by agarose gel electrophoresis before proceding to the immunoprecipitation, this step will take approximately $3 \mathrm{~h}$.

\section{Immunoprecipitation of modified nucleosomes (Steps 47-83) takes} approximately $20 \mathrm{hrs}$. However, this includes an overnight incubation of $14 \mathrm{~h}$ which creates a natural Pause Point.

a) Preparation of the antibody for immunoprecipitation (steps 47-62) will take approximately $2 \mathrm{~h}$ and must be completed before the overnight incubation. To save time, this can be done concurrently with steps $1-21$, or during the agarose gel electrophoresis step 44 .

b) On day 2, washing of the antibody, and elution will require approximately 4 to $6 \mathrm{~h}$ depending on the number of different antibodies studied in parallel.

5. Analysis of DNA associated with modified histones (steps $84-88$ ) takes approximately $3 \mathrm{~h}$ for each different qPCR study. 


\section{Troubleshooting}

Insert Table 4

\section{Anticipated Results:}

The procedure described above generates approximately $200 \mu \mathrm{g}$ of nucleic acid for MNase digestion from approximately $10^{7}$ mammalian cells. Conditions for the digesting the chromatin with MNase should be determined empirically to obtain a mixture of nucleosomal arrays consisting mainly of mononucleosomes (150-175 bp), but laddering up to at least trinucleosomes should be visible in UV light after treatment with ethidium bromide (See Figure 3A

- Digested nuclei). This will provide a resolution of approximately $500 \mathrm{bp}$ in ChIP analysis. Lysis of the nuclei in the presence of high salt leads to an efficient extraction of the chromatin that binds to the HAP resin to form a thick paste. Once transferred to the column and subjected to centrifugation, no chromatin should be released in the column flow-through. If chromatin is detected in the flow through, it is likely that you have not used the proper ratio of HAP resin to nucleic acid content. Similarly, no chromatin should be present in the wash fractions. In contrast, chromatin should be released within the first 2 elution steps (see Figure 3A). The chromatin eluted from the HAP column should be largely devoid of contaminating proteins that were present in the extracted chromatin 
prior to HAP binding (see Figure 3B). As shown by silver stained SDS-PAGE, only four protein species between 12 and $18 \mathrm{kDa}$, which represent histones $\mathrm{H} 3$, $\mathrm{H} 2 \mathrm{~B}, \mathrm{H} 2 \mathrm{~A}$, and $\mathrm{H} 4$ in descending order, are detected in the elution fractions. Furthermore, genomic DNA should be representative of all types of chromatin, including euchromatin, facultative heterochromatin, and constitutive heterochromatin (see Figure 2). Figure 4 exemplifies an application of this protocol to the study of dimethylation and trimethylation of H3K4 across the myogenin locus. In differentiating myoblasts, when the myogenin gene is actively transcribed, we observe that the promoter region is preferentially marked by dimethylation at histone $\mathrm{H} 3$ lysine $4(\mathrm{H} 3 \mathrm{~K} 4 \mathrm{me} 2)$, while the transcribed region of the gene is marked by trimethylation at histone $\mathrm{H} 3$ lysine 4 (H3K4me3). Using these antibodies, we observe a 1.5- to 2-fold greater enrichment of histones modifications compared to X-ChIPs performed using the same primer/probe sets (data not shown). However, the fold enrichment observed in HAP-NChIP compared to X-ChIP depends on the antibody used, and can be 20- to 50-fold greater for some antibodies (data not shown). We believe that this difference likely reflects the degree to which the modification is sterically hindered under XChIP conditions, as well as the differential ability of antibodies to recognize their target in X-linked conditions. Indeed, the anti $-\mathrm{H} 3 \mathrm{~K} 4 \mathrm{me} 2$ and $-\mathrm{H} 3 \mathrm{~K} 4 \mathrm{me} 3$ antibodies have been used quite extensively in the literature to localize these marks to active genes and as such appear quite efficient in X-ChIP conditions. Finally, when assessing a ChIP study, you must keep in mind the quality of the 
antibodies with respect to their specificity (i.e. how many fold greater is their affinity for the modified histone versus unmodified histone). Thus, it should be remembered that quality of the ChIP analysis is very dependent upon the quality of the antibody that is used for immunoprecipitation.

In conclusion, this HAP-NChIP protocol provides a method to alleviate the problem of steric hindrance caused by cofactors which mask antibody epitopes. However, the problem of steric hindrance caused by multiple covalent modifications on the same histone tail is not remedied by this technique. Overcoming this problem will require the development of new antibodies that recognize multiple covalent modifications in tandem. While some antibodies recognizing multiple histone modifications do exist, a better understanding of the histone code is necessary to comprehend the inter-relationship between these different covalent marks. Only then will we be able to begin to rationally designing antibodies that will overcome the steric hindrance of multiple histone modifications, and bring us closer to elucidating the mechanism by which these modifications regulate gene expression.

\section{Acknowledgements:}

This work was supported by grants from the Canadian Institutes of Health Research, Muscular Dystrophy Association, and the Stem Cell Network (to 
F.J.D.); and Terry Fox Foundation/National Cancer Institute of Canada, and

Human Frontiers Science Program (to M.B.). F.J.D. holds a Canadian Research Chair in Epigenetic Regulation of Transcription. M.B. holds a Canadian Research Chair in the Regulation of Gene Expression.

\section{COMPETING INTERESTS STATEMENT}

The authors declare that they have no competing financial interests.

\section{References:}

1. Hebbes, T.R., Thorne, A.W. \& Crane-Robinson, C. A direct link between core histone acetylation and transcriptionally active chromatin. Embo $\mathrm{J} 7$, 1395-402 (1988).

2. O'Neill, L.P. \& Turner, B.M. Immunoprecipitation of native chromatin: NChIP. Methods 31, 76-82 (2003).

3. O'Neill, L.P., VerMilyea, M.D. \& Turner, B.M. Epigenetic characterization of the early embryo with a chromatin immunoprecipitation protocol applicable to small cell populations. Nat Genet 38, 835-41 (2006).

4. Weber, M. et al. Chromosome-wide and promoter-specific analyses identify sites of differential DNA methylation in normal and transformed human cells. Nat Genet 37, 853-62 (2005).

5. Dorbic, T. \& Wittig, B. Isolation of oligonucleosomes from active chromatin using HMG17-specific monoclonal antibodies. Nucleic Acids Res 14, 3363-76 (1986).

6. Solomon, M.J., Larsen, P.L. \& Varshavsky, A. Mapping protein-DNA interactions in vivo with formaldehyde: evidence that histone $\mathrm{H} 4$ is retained on a highly transcribed gene. Cell 53, 937-47 (1988).

7. Orlando, V., Strutt, H. \& Paro, R. Analysis of chromatin structure by in vivo formaldehyde cross-linking. Methods 11, 205-14. (1997).

8. Dhalluin, C. et al. Structure and ligand of a histone acetyltransferase bromodomain. Nature 399, 491-6 (1999).

9. Santos-Rosa, $\mathrm{H}$. et al. Methylation of histone H3 K4 mediates association of the isw1p ATPase with chromatin. Mol Cell 12, 1325-32 (2003).

10. Wysocka, J. et al. A PHD finger of NURF couples histone H3 lysine 4 trimethylation with chromatin remodelling. Nature 442, 86-90 (2006).

11. Strahl, B.D. \& Allis, C.D. The language of covalent histone modifications. Nature 403, 41-5 (2000). 
12. Ruthenburg, A.J., Allis, C.D. \& Wysocka, J. Methylation of lysine 4 on histone H3: intricacy of writing and reading a single epigenetic mark. $\mathrm{Mol}$ Cell 25, 15-30 (2007).

13. Vermeulen, M. et al. Selective anchoring of TFIID to nucleosomes by trimethylation of histone $\mathrm{H} 3$ lysine 4. Cell 131, 58-69 (2007).

14. Bernardi, G. Chromatography of nucleic acids on hydroxyapatite. Nature 206, 779-83 (1965).

15. Thorne, A.W., Cary, P.D. \& Crane-Robinson, C. Extraction and separation of core histone and non-histone chromosomal proteins. in Chromatin: $A$ practical approach, Vol. 9 (ed. Gould, H.) 35-57 (Oxford University Press, Oxford, 1998).

16. Rampalli, S. et al. p38 MAPK signaling regulates recruitment of Ash2Lcontaining methyltransferase complexes to specific genes during differentiation. Nat Struct Mol Biol 14, 1150-1156 (2007).

17. Ren, B. et al. Genome-wide location and function of DNA binding proteins. Science 290, 2306-9 (2000).

18. Lee, T.I., Johnstone, S.E. \& Young, R.A. Chromatin immunoprecipitation and microarray-based analysis of protein location. Nat Protoc 1, 729-48 (2006).

19. Mikkelsen, T.S. et al. Genome-wide maps of chromatin state in pluripotent and lineage-committed cells. Nature 448, 553-60 (2007).

20. Hager, G.L. \& Fragoso, G. Analysis of nucleosome positioning in mammalian cells. Methods Enzymo/ 304, 626-38 (1999).

21. Lomvardas, S. \& Thanos, D. Modifying gene expression programs by altering core promoter chromatin architecture. Cell 110, 261-71. (2002).

22. Sambrook, J. \& Russell, D.W. Molecular Cloning: A Laboratory Manual, (Cold Spring Laboratory Press, New York, 2001). 
Figures Legends:

Figure 1. Flowchart of the different steps of the HAP-NChIP protocol.

Figure 2. Analysis of loci representation in chromatin eluted from HAP column. DNA isolated from either the chromatin fractions purified using HAP chromatography or $\mathrm{C} 2 \mathrm{C} 12$ cell genomic DNA were subjected to $\mathrm{qPCR}$ using primers that recognize the indicated genomic loci. The absolute representation of loci lying in euchromatin (Ckm, and Myog), facultative heterochromatin (lgG), and constitutive heterochromatin ( $\gamma$ satellite DNA) was determined by generating a standard curve of $\mathrm{Ct}$ values for each primer set using the genomic DNA, and then determining the amount of genomic DNA which provides the same Ct as an aliquot of the HAP eluted chromatin. Average values of triplicate qPCR reactions are displayed with error bars corresponding to \pm s.d.

Figure 3. Analysis of nucleosomes isolated by hydroxyapatite chromatography. A) Nucleosomal arrays isolated from $\mathrm{C} 2 \mathrm{C} 12$ nuclei treated with micrococcal nuclease were subjected to purification using hydroxyapatite. Fractions obtained from steps 16 (Undigested Nuclei), 21 (Digested Nuclei), 26 (HAP FT), 28 (HAP Wash600), 31 (HAP Wash100), and 34-35 (HAP Elution 1-3), were deproteinized and separated on a $1.2 \%$ agarose gel in Tris-Glycine buffer. B) A $6 \mu \mathrm{L}$ aliquot of the fractions obtained in steps 21 (Digested Nuclei), and 34- 
35 (HAP Elutions 1-3) were diluted to $8 \mu \mathrm{L}$ with SDS-PAGE gel-loading buffer, and boiled for 5 min. Proteins were then separated on a 12\% SDS-PAGE gel and visualized using silver stain.

Figure 4. Distribution of H3K4me2 and H3K4me3 across the Myog locus. A) Schematic representation of the Myog gene locus. The numbers 1 through 4 represent the position of primer sets used in the ChIP studies. B) Native ChIP analysis was used to measure relative enrichment of H3K4me2 and H3K4me3 at various locations along the Myog locus in differentiating (48 h) $\mathrm{C} 2 \mathrm{C} 12$ cells as described above. Resolution of the native ChIP was $\sim 500$ bp after micrococcal nuclease digestion. Relative enrichment is expressed as the signal observed on the Myog gene with respect to that observed at the inactive Igh gene. Average values of duplicate qPCR reactions are displayed with error bars corresponding to \pm s.d. Each experiment was performed at least twice independently ${ }^{16}$. Reproduced with permission from Nature Structural and Molecular Biology. 


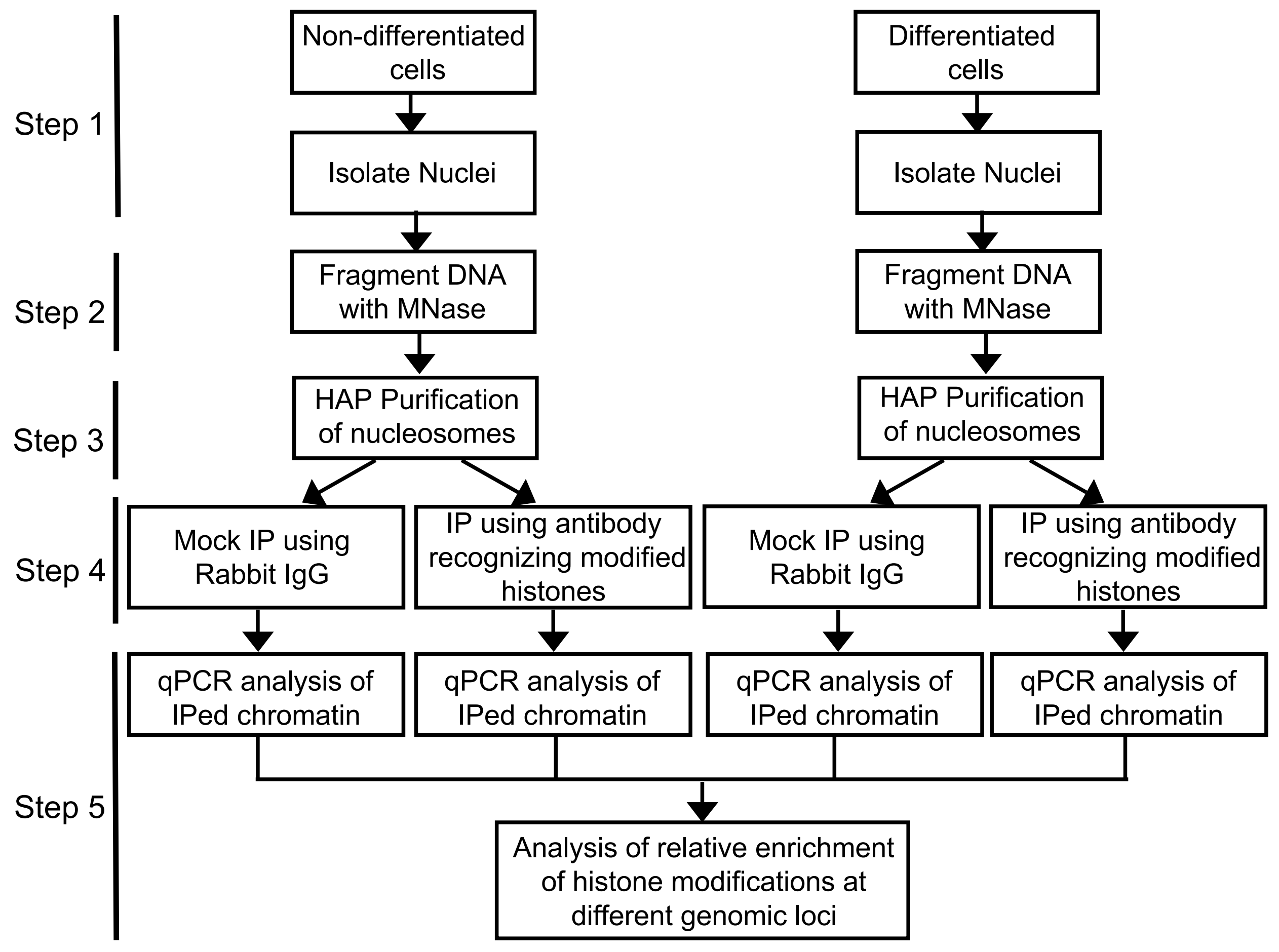




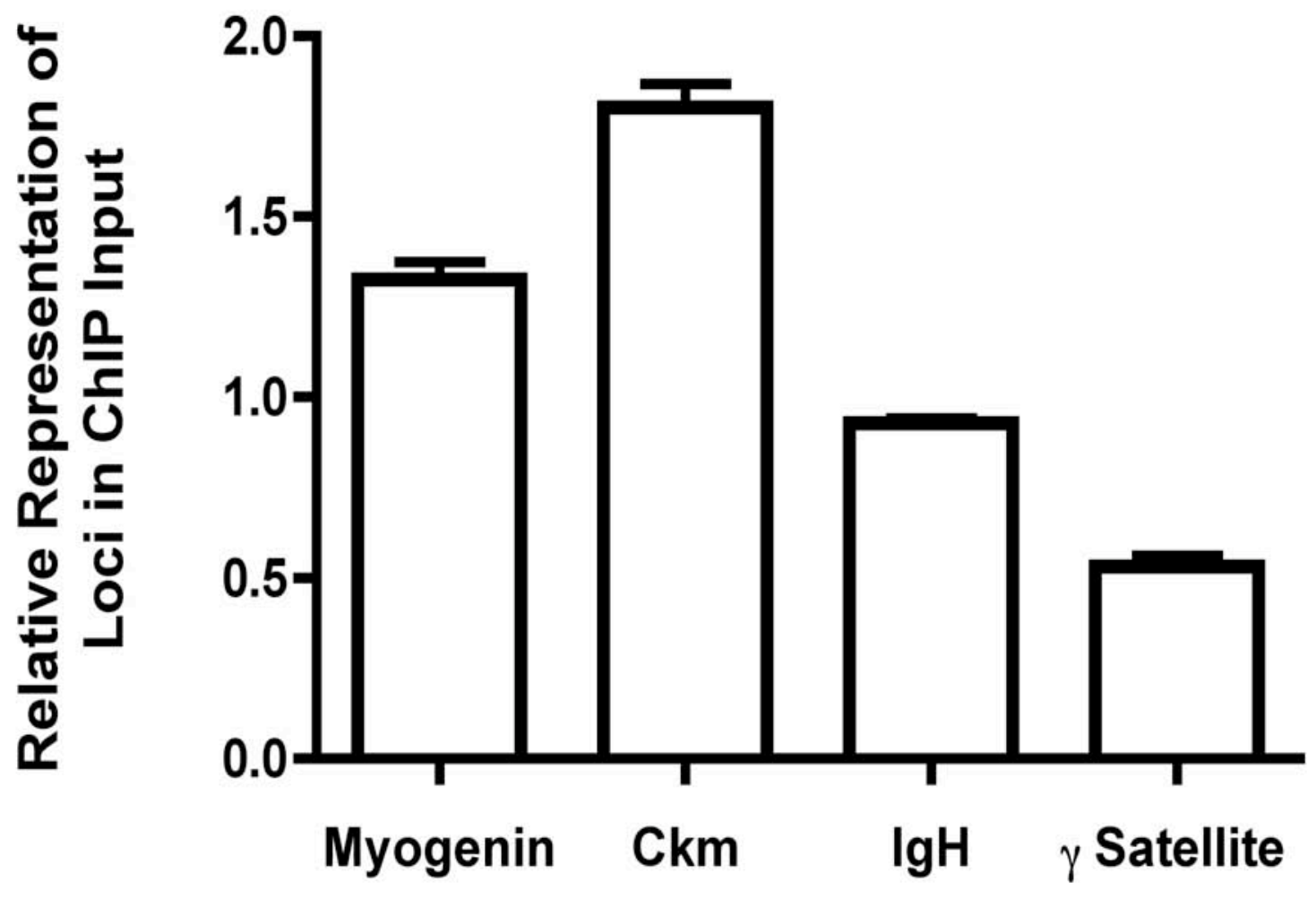




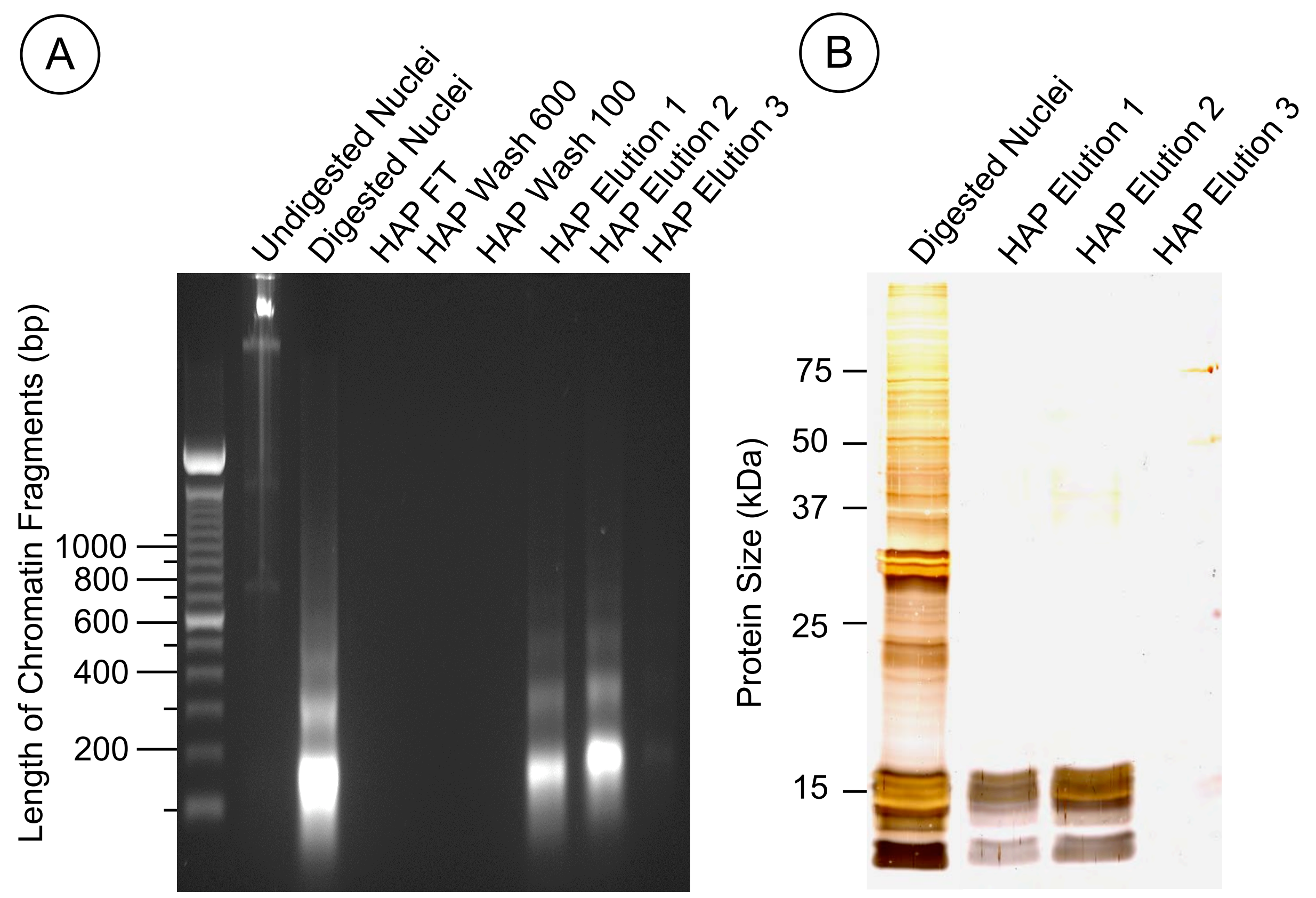


(A)

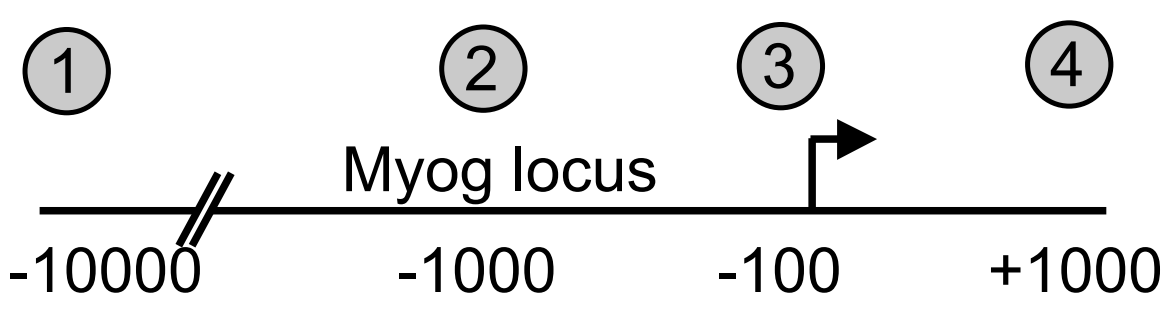

(B)

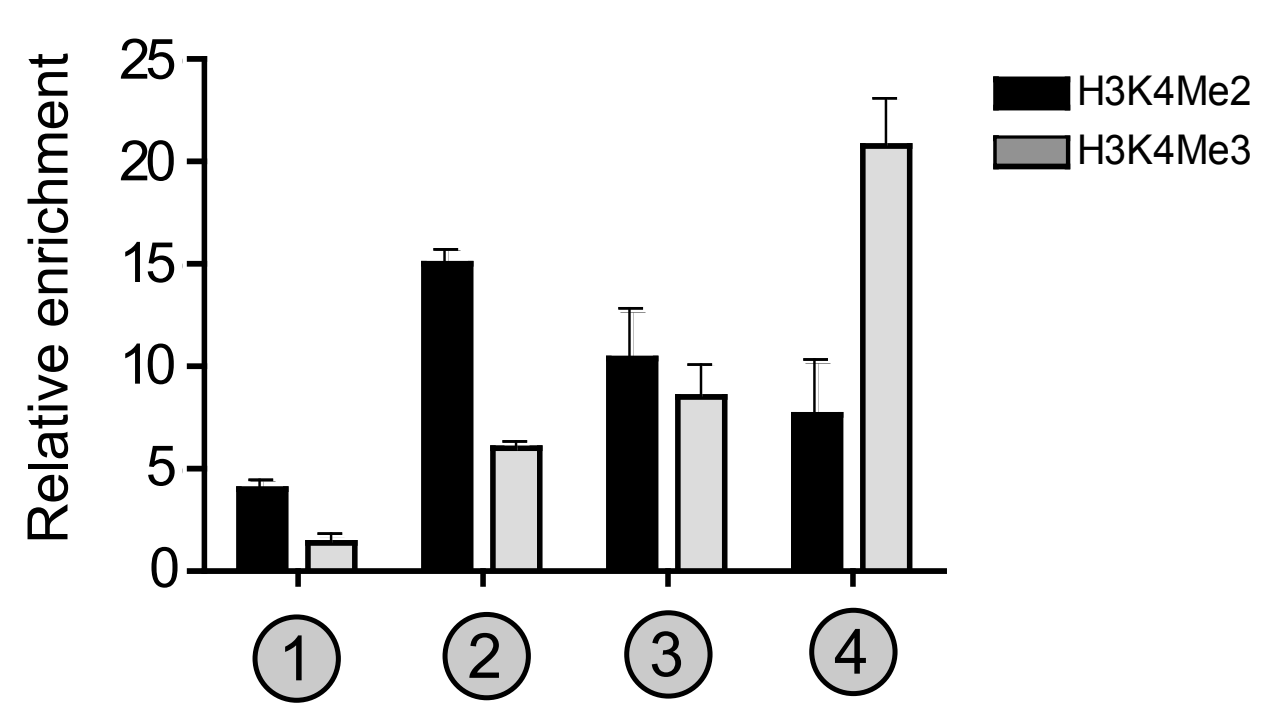


Table 1. Example of spectrophotometer readings that can be expected when measuring nucleic acid concentration in nuclei. To determine the nucleic acid concentration, $4 \mu \mathrm{L}$ of resuspended nuclei were diluted in $400 \mu \mathrm{L}$ of $2 \mathrm{M} \mathrm{NaCl}$ (1 in 100 dilution). Nucleic acid content is then estimated based on the molar extinction coefficient for DNA (50 $\mathrm{ng} / \mu \mathrm{L})$.
$\mathrm{A}_{260} / \mathrm{A}_{280}=1.58$
$A_{230}=0.204$
$A_{260} / A_{230}=1.12$
$A_{260}=0.227$
$\mathrm{A}_{280}=0.144$
$A_{320}=0.031$

Concentration of DNA $=$ OD260 $\times$ dilution factor $\times 50 \mathrm{ng} / \mathrm{mL}$

$=0.227 \times 100 \times 50 \mathrm{ng} / \mu \mathrm{L}$

$=\quad 1146.7 \mathrm{ng} / \mu \mathrm{L}$ 
Table 2. Set Up of Master Mix for qPCR analysis.

\begin{tabular}{|c|c|c|c|}
\hline Reagent & $\begin{array}{c}\text { Final Conc. } \\
\text { in Rx }\end{array}$ & Amount $(\boldsymbol{\mu L}$ ) in 1 Rx & $\begin{array}{c}\text { Master Mix for 72 samples } \\
\text { \#samples+3=72) }\end{array}$ \\
\hline $\mathrm{H} 2 \mathrm{O}$ & $\mathrm{NA}$ & $8.65 \mu \mathrm{L}$ & $623 \mu \mathrm{l}$ \\
\hline $10 \mathrm{X} \mathrm{Buffer}$ & 1 & $2.50 \mu \mathrm{L}$ & $180 \mu \mathrm{l}$ \\
\hline $\mathrm{MgCl}_{2} 25 \mathrm{mM}$ & $5.5 \mathrm{mM}$ & $5.50 \mu \mathrm{L}$ & $396 \mu \mathrm{l}$ \\
\hline $\mathrm{dA} 10 \mathrm{mM}$ & $200 \mu \mathrm{M}$ & $0.50 \mu \mathrm{L}$ & $36 \mu \mathrm{l}$ \\
\hline $\mathrm{dC} 10 \mathrm{mM}$ & $200 \mu \mathrm{M}$ & $0.50 \mu \mathrm{L}$ & $36 \mu \mathrm{l}$ \\
\hline $\mathrm{dG} 10 \mathrm{mM}$ & $200 \mu \mathrm{M}$ & $0.50 \mu \mathrm{L}$ & $36 \mu \mathrm{l}$ \\
\hline $\mathrm{dT} 20 \mathrm{mM}$ & $400 \mu \mathrm{M}$ & $0.50 \mu \mathrm{L}$ & $36 \mu \mathrm{l}$ \\
\hline $\begin{array}{c}\text { Forward primer } \\
10 \text { pmol/ } \mu \mathrm{L}\end{array}$ & $200 \mathrm{nM}$ & $0.50 \mu \mathrm{L}$ & $36 \mu \mathrm{l}$ \\
\hline $\begin{array}{c}\text { Reverse primer } \\
10 \text { pmol/ } \mu \mathrm{L}\end{array}$ & $200 \mathrm{nM}$ & $0.50 \mu \mathrm{L}$ & $18 \mu \mathrm{l}$ \\
\hline $\begin{array}{c}\text { TaqMan probe } \\
10 \mathrm{pmol} / \mu \mathrm{L}\end{array}$ & $100 \mathrm{nM}$ & $0.25 \mu \mathrm{L}$ & $7.2 \mu \mathrm{l}$ \\
\hline $\begin{array}{c}\text { AmpliTaq Gold } \\
5 \mathrm{U} / \mathrm{rxn}\end{array}$ & $0.5 \mathrm{U}$ & $0.10 \mu \mathrm{L}$ & $1440 \mu \mathrm{l}$ \\
\hline TOTAL & & $20.00 \mu \mathrm{L}$ & None \\
\hline DNA & $2 \mathrm{ng}$ to 100 & $5.00 \mu \mathrm{L}$ & \\
\hline
\end{tabular}


Table 3. Example of qPCR analysis of three different epigenetic modifications at a specific gene loci both before and after differentiation. Chromatin immunoprecipitation was prepared on nucleosomes isolated from $\mathrm{C} 2 \mathrm{C} 12$ cells under growth $(\mathrm{A})$ or differentiation(B) conditions. Biological samples are analyzed in triplicate for 3 test antibodies (H3K4me2, H3K4me3, and H4ac), and a mock immunoprecipitation. A serial dilution of mouse genomic DNA is used to establish relative quantitation of the immunoprecipitated DNA.

\begin{tabular}{|c|c|c|c|}
\hline Tube & Sample & Tube & Sample \\
\hline 1 & Input Oh-A & 37 & H3K4me3 oh-A \\
\hline 2 & Input Oh-A & 38 & H3K4me3 oh - A \\
\hline 3 & Input $0 \mathrm{~h}-\mathrm{A}$ & 39 & H3K4me3 0h-A \\
\hline 4 & Input $0 \mathrm{~h}-\mathrm{B}$ & 40 & H3K4me3 $0 \mathrm{~h}-\mathrm{B}$ \\
\hline 5 & Input Oh-B & 41 & H3K4me3 o h - B \\
\hline 6 & Input Oh-B & 42 & H3K4me3 0 h - B \\
\hline 7 & Input $48 \mathrm{~h}-\mathrm{A}$ & 43 & H3K4me3 48 h-A \\
\hline 8 & Input $48 \mathrm{~h}-\mathrm{A}$ & 44 & H3K4me3 48 h-A \\
\hline 9 & Input $48 \mathrm{~h}-\mathrm{A}$ & 45 & H3K4me3 48h-A \\
\hline 10 & Input $48 \mathrm{~h}-\mathrm{B}$ & 46 & H3K4me3 48 h - B \\
\hline 11 & Input $48 \mathrm{~h}-\mathrm{B}$ & 47 & H3K4me3 48 h - B \\
\hline 12 & Input $48 \mathrm{~h}-\mathrm{B}$ & 48 & H3K4me3 48 h - B \\
\hline 13 & Mock $0 \mathrm{~h}-\mathrm{A}$ & 49 & $\mathrm{H} 4 \mathrm{ac} 0 \mathrm{~h}-\mathrm{A}$ \\
\hline 14 & Mock O h - A & 50 & $\mathrm{H} 4 \mathrm{ac} 0 \mathrm{~h}-\mathrm{A}$ \\
\hline 15 & Mock O h - A & 51 & $\mathrm{H} 4 \mathrm{ac} 0 \mathrm{~h}-\mathrm{A}$ \\
\hline 16 & Mock O h - B & 52 & $\mathrm{H} 4 \mathrm{ac} 0 \mathrm{~h}-\mathrm{B}$ \\
\hline 17 & Mock O h - B & 53 & $\mathrm{H} 4 \mathrm{ac} 0 \mathrm{~h}-\mathrm{B}$ \\
\hline 18 & Mock O h - B & 54 & $\mathrm{H} 4 \mathrm{ac} 0 \mathrm{~h}-\mathrm{B}$ \\
\hline 19 & Mock 48h-A & 55 & H4ac 48h - A \\
\hline 20 & Mock 48 h-A & 56 & H4ac 48 h-A \\
\hline 21 & Mock 48 h-A & 57 & H4ac 48 h-A \\
\hline 22 & Mock 48 h-B & 58 & $\mathrm{H} 4 \mathrm{ac} 48 \mathrm{~h}-\mathrm{B}$ \\
\hline 23 & Mock 48 h-B & 59 & $\mathrm{H} 4 \mathrm{ac} 48 \mathrm{~h}-\mathrm{B}$ \\
\hline 24 & Mock 48 h-B & 60 & $\mathrm{H} 4 \mathrm{ac} 48 \mathrm{~h}-\mathrm{B}$ \\
\hline 25 & H3K4me2 Oh-A & 61 & No Template Control \\
\hline 26 & H3K4me2 Oh-A & 62 & No Template Control \\
\hline 27 & H3K4me2 Oh-A & 63 & No Template Control \\
\hline 28 & H3K4me2 o h - B & 64 & Std - Mouse DNA $50 \mathrm{ng}$ \\
\hline 29 & H3K4me2 O h-B & 65 & Std - Mouse DNA $10 \mathrm{ng}$ \\
\hline 30 & H3K4me2 Oh-B & 66 & Std - Mouse DNA 2 ng \\
\hline 31 & H3K4me2 $48 \mathrm{~h}-\mathrm{A}$ & 67 & Std - Mouse DNA $400 \mathrm{pg}$ \\
\hline 32 & H3K4me2 48 h - A & 68 & Std - Mouse DNA $80 \mathrm{pg}$ \\
\hline 33 & H3K4me2 $48 \mathrm{~h}-\mathrm{A}$ & 69 & Std - Mouse DNA $16 \mathrm{pg}$ \\
\hline 34 & H3K4me2 48 h - B & 70 & \\
\hline 35 & H3K4me2 $48 \mathrm{~h}-\mathrm{B}$ & 71 & \\
\hline 36 & H3K4me2 $48 \mathrm{~h}-\mathrm{B}$ & 72 & \\
\hline
\end{tabular}


